\title{
Review \\ Clinical Significance of COVID-19 and Diabetes: In the Pandemic Situation of SARS-CoV-2 Variants including Omicron (B.1.1.529)
}

\author{
Akiko Yonekawa ${ }^{1, *}$ and Nobuyuki Shimono ${ }^{2,3}$ (D) \\ 1 Department of Medicine and Biosystemic Science, Graduate School of Medical Sciences, Kyushu University, \\ Fukuoka 812-8582, Japan \\ 2 Department of General Internal Medicine, Kyushu University Hospital, Fukuoka 812-8582, Japan; \\ shimono.nobuyuki.679@m.kyushu-u.ac.jp \\ 3 Center for the Study of Global Infection, Kyushu University Hospital, Fukuoka 812-8582, Japan \\ * Correspondence: yonekawa.a.a27@m.kyushu-u.ac.jp
}

Citation: Yonekawa, A.; Shimono, N. Clinical Significance of COVID-19 and Diabetes: In the Pandemic Situation of SARS-CoV-2 Variants including Omicron (B.1.1.529). Biology 2022, 11, 400. https://doi.org/10.3390/ biology11030400

Academic Editors: Seiho Nagafuchi and Ligen $\mathrm{Yu}$

Received: 7 December 2021

Accepted: 3 March 2022

Published: 4 March 2022

Publisher's Note: MDPI stays neutral with regard to jurisdictional claims in published maps and institutional affiliations.

Copyright: (c) 2022 by the authors Licensee MDPI, Basel, Switzerland. This article is an open access article distributed under the terms and conditions of the Creative Commons Attribution (CC BY) license (https:// creativecommons.org/licenses/by/ $4.0 /)$.
Simple Summary: Amidst the dual pandemics of diabetes and coronavirus disease 2019 (COVID-19), with the constant emergence of novel variants of severe acute respiratory syndrome coronavirus 2 (SARS-CoV-2), a vicious cycle has been created, i.e., a hyperglycemic state contributes to the severe clinical course of COVID-19, which in turn has deleterious effects on glycometabolism and in some cases causes new-onset diabetes. Here, we present a comprehensive review of the current literature on the clinical and experimental findings associated with the interrelationship between diabetes and COVID-19. To control disease outcomes and glucometabolic complications in COVID-19, this issue is still being investigated.

\begin{abstract}
The coronavirus disease 2019 (COVID-19) global pandemic, which is caused by severe acute respiratory syndrome coronavirus 2 (SARS-CoV-2), remains uncontrolled, with the spread of emerging variants. According to accumulating evidence, diabetes is one of the leading risk factors for a severe COVID-19 clinical course, depending on the glycemic state before admission and during COVID-19 hospitalization. Multiple factors are thought to be responsible, including an altered immune response, coexisting comorbidity, and disruption of the renin-angiotensin system through the virus-host interaction. However, the precise underlying mechanisms remain under investigation. Alternatively, the focus is currently on the diabetogenic and ketosis-prone potential of SARS-CoV-2 itself, even for probable triggers of stress and steroid-induced hyperglycemia in COVID-19. In this article, we present a comprehensive review of the recent literature on the clinical and experimental findings associated with diabetes and COVID-19, and we discuss their bidirectional relationship, i.e., the risk for an adverse prognosis and the deleterious effects on glycometabolism. Accurate assessments of the incidence of new-onset diabetes induced by COVID-19 and its pathogenicity are still unknown, especially in the context of the circulation of SARS-CoV-2 variants, such as Omicron (B.1.1.529), which is a major challenge for the future.
\end{abstract}

Keywords: SARS-CoV-2; COVID-19; diabetes; hyperinflammation; hyperglycemia; new-onset diabetes; Omicron variant

\section{Introduction}

Among the global outbreaks of the modern age, coronavirus disease 2019 (COVID-19) has become second only to the Spanish flu in terms of the number of deaths due to respiratory virus diseases [1]. Until 14 February 2022, i.e., in a little more than 2 years after the outbreak was announced in Wuhan, there have been 410,565,868 confirmed cases of COVID-19 worldwide, including 5,810,880 deaths (WHO Coronavirus (COVID-19) Dashboard. Available online: https: / / covid19.who.int (accessed on 14 February 2022). Despite 
global efforts for disease control, COVID-19 remains uncontrolled, and the constant emergence of novel variants of severe acute respiratory syndrome coronavirus 2 (SARS-CoV-2) make the problem even more intractable. Individuals infected with SARS-CoV-2 present with a broad spectrum of clinical manifestations, from asymptomatic to lethal. This suggests that not only the virus antigenicity but also host factors, such as age, sex, underlying health conditions, and genetic characteristics, may affect the natural history of COVID-19.

Diabetes is highly prevalent. In 2019, the global prevalence of diabetes in adult people aged $20-79$ was estimated to be $9.3 \%$ (463 million people), which is predicted to continue increasing [2]. Diabetes is a heterogeneous disease that is divided into several subtypes as follows: type 1 diabetes (due to autoimmune $\beta$-cell destruction), type 2 diabetes (due to a progressive loss of adequate $\beta$-cell insulin secretion frequently on the background of insulin resistance), specific types due to other causes, and gestational diabetes [3]. The association between diabetes and infection is classically well known, and diabetes is an established risk factor for contracting infectious diseases with a high frequency and increased severity $[4,5]$.

Diabetes has been shown to be one of the leading risk factors for poor outcomes in COVID-19 [6-9]. Additionally, emerging data reveal that COVID-19 itself dysregulates glucose homeostasis and may develop diabetes [10]. In this review, we focus on the clinical and experimental findings associated with diabetes and COVID-19 and discuss the bidirectional interrelationships between these diseases.

\section{Risk of Diabetes as the Underlying Disease of COVID-19}

\subsection{Risk of SARS-CoV-2 Infection in Diabetes}

Initially, we must distinguish between disease susceptibility and prognosis to assess risk. Patients with diabetes are generally more susceptible to infections. This is thought to be due to hyperglycemia that causes immune cells to malfunction, such as the reduction of the ability of chemotaxis, phagocytosis, and bactericidal action of polynuclear neutrophils $[4,11]$. Affected diabetes [11] and poor glycemic control [5] are risks of acquiring certain infections and of aggravating viral infections, including SARS $[12,13]$ and pandemic influenza (H1N1 pdm09) [14].

The high prevalence of diabetes was reported in several studies (33.8\% [15], 26.6\% [16], $24 \%$ [17], and 19\% [18]). A large study that included more than 5,000 individuals in the New York City reported high prevalence rates of diabetes (22.6\%) [19]. However, the prevalence of diabetes in non-admitted patients was $9.7 \%$ compared with $34.7 \%$ in admitted patients [19]. The Centers for Disease Control and Prevention reported that participants, including outpatients, had a prevalence of diabetes of $10.9 \%$ compared with $10.1 \%$ of diagnosed diabetes among adults in the United States based on 2018 data [20]. Similarly, an observational study in Japan showed that diabetes without complications was $14.2 \%$ of registered COVID-19 patients, whereas diabetes is present in approximately $12 \%$ of people of the same generation [21]. In a meta-analysis reported by Pugliese et al., the prevalence of diabetes among COVID-19 patients was not higher than that of the general population, in China, Europe, and the United States [22]. Therefore, it is not epidemiologically obvious whether diabetes carries a significant risk of SARS-CoV-2 infection.

\subsection{Significance of Diabetes for Increasing the Severity and Poor Outcome in COVID-19}

Accumulating evidence shows that diabetes is the risk factor for the progression to severe disease in COVID-19.

An early study in China saw that the case fatality rate was threefold higher in people with pre-existing diabetes than in those without diabetes (7.3\% vs. $2.3 \%$ ) [6]. In a study of the whole population of England, of the 23,698 in-hospital COVID-19-related deaths, $31.4 \%$ had type 2 diabetes, $1.5 \%$ had type 1 diabetes, and $0.3 \%$ had other types of diabetes; moreover, both type 1 and type 2 diabetes were independently associated with a significant increase in COVID-19-related mortality (adjusted odds 2.86 (2.58-3.18) for type 1 diabetes and 1.80 (1.75-1.86) for type 2 diabetes) [7]. Regarding the fatal and critical care unit-treated COVID-19, a whole population study in Scotland found that the adjusted odds ratios (ORs) 
for diabetes were 1.395 (1.304-1.494), with 2.396 (1.815-3.163) for type 1 diabetes and 1.369 (1.276-1.468) for type 2 [8]. In a single-center prospective cohort study conducted in the United States, Gregory et al. initially reported that people with type 1 and type 2 diabetes showed similar risks for hospitalization and greater illness severity [9]. Their subsequent analyses from the data that included a higher number of cases showed that patients with type 1 diabetes had a higher risk for hospitalization than those with type 2 diabetes (adjusted ORs for type 1: 4.60, 95\% confidence interval (CI) 3.04-6.98; type 2: 3.42, 95\% CI 2.94-3.99) [23]. More recently, these authors assessed the risk of type 1 diabetes among pediatric patients. A total of 22 cases of pediatric patients with type 1 diabetes were included, and they had unadjusted ORs of 20.49 (95\% CI 8.63-48.62) for hospitalization and 19.39 (95\% CI 8.47-44.42) for greater severity, as compared with pediatric patients without diabetes [9].

\subsection{Comorbidity of Diabetes}

Diabetes often coexists with various comorbidities, such as hypertension, obesity, cardiovascular disease, and chronic kidney disease. It is highly possible that the overlapping of comorbidities has some additional effects on the risk of adverse outcomes. Particularly, there is a close relationship between obesity and type 2 diabetes, which is described as "diabesity".

Obesity is independently associated with risk factors for severe COVID-19. In a large retrospective analysis of body mass index (BMI) in New York City, obesity, defined as BMI $\geq 30 \mathrm{~kg} / \mathrm{m}^{2}$, was found to be significantly associated with increased admission to the hospital and critical care [24]. A single-center retrospective cohort study in France found that severe obesity, defined as BMI $\geq 35 \mathrm{~kg} / \mathrm{m}^{2}$, was associated with an increased requirement for mechanical ventilation in the critical setting [25].

The risk of obesity has been assessed in diabetes patients. A population-based cohort study in England reported higher mortality rates in people with a BMI $>40.0 \mathrm{~kg} / \mathrm{m}^{2}$ compared with individuals with a BMI of $25.0-29.9 \mathrm{~kg} / \mathrm{m}^{2}$ (hazard ratio (HR) 2.33 and 1.60 for type 1 and type 2 diabetes, respectively) [26]. A U-shaped association was detected between BMI and COVID-19-related mortality (BMI of $<20.0 \mathrm{~kg} / \mathrm{m}^{2}$, HR 2.45 and 2.33 for type 1 and type 2 diabetes, respectively) [26]. In a nationwide multicenter observational study conducted in France (the CORONADO (Coronavirus SARS-CoV-2 and Diabetes Outcomes) study), BMI was also independently associated with the primary outcome of tracheal intubation for mechanical ventilation and/or death within 7 days of admission (OR $1.28,1.10-1.47)$ in people with diabetes. When considering death on day 7 , this association with BMI was not statistically significant. Of note, BMI $\geq 40 \mathrm{~kg} / \mathrm{m}^{2}$ has less impact on the primary outcome than BMI $25-39.9 \mathrm{~kg} / \mathrm{m}^{2}$ [27]. In an additional analysis of type 2 diabetes in the CORONADO study, the impact of obesity on COVID-19 prognosis was no longer observed among older patients aged $\geq 75$ years [28].

The mechanisms by which obesity affects unfavorable outcomes remain obscure. The characteristic factors of obesity, such as a chronic low-grade inflammation state and an altered immune response [29], are potentially associated. Impaired respiratory function is one explanation for the increased need for mechanical ventilation support, as it arises from pulmonary restriction, decreased lung volume, and impaired lung perfusion [30]. To determine the BMI cutoff value at which patients are at risk for aggravation, as well as the pathogenicity of obesity in older adults, further studies are needed.

\section{Role of Glycemic Control in Patients with COVID-19}

\subsection{Glycemic Control before Hospital Admission}

An early study in China reported that poorly controlled diabetes with $\mathrm{HbA1c} \geq 7.0 \%$ (53 mmol/mol) was associated with increased severity of lung lesions and a higher rate of poor clinical prognosis, including deaths, using mechanical ventilation, and admission to the intensive care unit (ICU), as compared with non-diabetes [31]. Subsequently, several studies have analyzed the association of $\mathrm{HbA1c}$ levels as an indicator of long-term glycemic 
control (Supplementary Table S1). Based on an analysis using a primary care electronic health records analytic platform in England, diabetes increased the risk of COVID-19related death compared with nondiabetic patients (adjusted HR 1.31, 95\% CI 1.01-1.26 for controlled diabetes with $\mathrm{HbA} 1 \mathrm{c}<7.5 \%$; adjusted HR 1.95, 95\% CI 1.83-2.08 for uncontrolled diabetes with $\mathrm{HbA} 1 \mathrm{c} \geq 7.5 \%$ ) [32]. In another nationwide population-based cohort study in England, as the HbA1c level increased, the COVID-19-related mortality rate also increased in both type 1 diabetes and type 2 diabetes (type 1 diabetes HR 2.23 and type 2 diabetes: HR 1.61 for $\mathrm{HbA} 1 \mathrm{c}$ of $\geq 10.0 \%$ compared with people with $\mathrm{HbA1c}$ of $6.5-7.0 \%$ [26]. However, in the CORONADO study, Cariou et al. showed that the HbA1c level was not associated with COVID-19 severity or 7 day mortality [27]. This discrepancy might arise from the short-term prognosis. It is probable that the patient's glycemic control status before hospital admission can affect the host immune system and diabetic complications, contributing to the risk of poor prognosis in COVID-19.

\subsection{Hyperglycemia at the Time of Hospital Admission}

Iacobellis et al. found that hyperglycemia on day 1 is the strongest predictor of chest radiographic abnormalities in hospitalized patients with COVID-19 [33]. Many studies have been reported on hyperglycemia at admission, although each study set different cutoff values for glucose levels (Supplementary Table S2).

Impaired fasting glucose levels at admission were shown to be associated with mortality [34-36], severity, including ICU admission [37-42], and in-hospital complications [34,43]. Klonoff et al. reported that in ICU inpatients, severe hyperglycemia (blood glucose $(\mathrm{BG})>13.88 \mathrm{mmol} / \mathrm{L}(250 \mathrm{mg} / \mathrm{dL}))$ on admission was associated with increased mortality (adjusted HR 3.14; 95\% CI 1.44-6.88) compared with BG < $7.77 \mathrm{mmol} / \mathrm{L}(140 \mathrm{mg} / \mathrm{dL})$ [44]. In a retrospective study conducted in China, hyperglycemia $(\geq 6.1 \mathrm{mmol} / \mathrm{L}(110 \mathrm{mg} / \mathrm{dL}))$ upon admission was an independent risk factor for progression to critical or lethal cases among noncritical cases (HR 1.30, 95\% CI 1.03-1.63, $p=0.026)$ and for in-hospital mortality in critical cases (HR 1.84, 95\% CI 1.14-2.98, $p=0.013$ ) [38].

Among patients with diabetes, poorly controlled hyperglycemia $(\mathrm{BG}>11 \mathrm{mmol} / \mathrm{L})$ may be associated with death and complications in COVID-19 [43]. Consistently, in ageand sex-adjusted nonlinear models in the CORONADO study, fasting plasma glucose (FPG) at admission was positively associated with tracheal intubation for mechanical ventilation and death within 7 days of admission $(p=0.0001)$ and with death on day 7 ( $p=0.0059)$ [27]. Notably, a strong association with hyperglycemia at admission was observed in subjects with no history of diagnosed diabetes compared with those with known diabetes $[34,40,45,46]$. In addition, Fadini et al. demonstrated that a higher FPG level at admission with each $2 \mathrm{mmol} / \mathrm{L}$ ( $36 \mathrm{mg} / \mathrm{dL}$ ) increase was associated with COVID-19 severity, with a stronger association among patients without diabetes than with diabetes (relative risk 1.21; 95\% CI 1.11-1.32; $p<0.001$ ) [40].

Hyperglycemia at admission, which reflects acute hyperglycemia, is a predictor of worse outcomes, even without a history of diabetes.

\subsection{Glycemic Control during In-Hospital Treatment}

Klonoff et al. reported that severe hyperglycemia (BG > $13.88 \mathrm{mmol} / \mathrm{L}(250 \mathrm{mg} / \mathrm{dL}))$ on days 2-3 was an independent risk factor for high mortality (adjusted HR 7.17; 95\% CI 2.62-19.62) compared with BG $<7.77 \mathrm{mmol} / \mathrm{L}(140 \mathrm{mg} / \mathrm{dL})$ in non-ICU patients [44]. $\mathrm{Wu}$ et al. showed that a median glucose level of $6.1 \mathrm{mmol} / \mathrm{L}(110 \mathrm{mg} / \mathrm{dL})$ or higher during the hospital stay or after critical diagnosis was independently associated with an increased risk for in-hospital mortality and progression to critical or lethal cases in critical cases [38]. In a multicenter retrospective observational study conducted in the United States, a subset analysis showed that the mortality rate was higher in people with uncontrolled hyperglycemia without diagnosed diabetes $(>10.0 \mathrm{mmol}(180 \mathrm{mg} / \mathrm{dL})$ and $\mathrm{HbA} 1 \mathrm{c}<6.5 \%)$ than in those with controlled diabetes $(41.7 \%$ vs. $14.8 \%, p<0.01)$ [47]. In patients with type 2 diabetes, a propensity score-matched analysis in a multicenter retrospective cohort study 
in China demonstrated that patients with well-controlled BG (3.9-10.0 mmol/L (70-180 $\mathrm{mg} / \mathrm{dL})$ ) had a significantly lower all-cause mortality rate than those with poorly controlled BG (>10.0 mmol/L (180 mg/dL); adjusted HR 0.14; CI 0.03-0.06). The well-controlled group showed lower levels of poor prognostic indicators, such as serum C-reactive protein and D-dimer, and a reduced frequency of serious complications associated with COVID-19, such as acute respiratory distress syndrome, acute heart injury, acute kidney injury, septic shock, and disseminated intravascular coagulation [48] (Supplementary Table S3).

Glycemic control has been shown to be important for improving disease prognosis. Sardu et al. demonstrated that glycemic control with insulin infusion decreased the levels of interleukin (IL)-6 and D-dimer and improved the prognosis in hyperglycemic inpatients with moderate COVID-19 [49]. They also reported that decreased BG levels from baseline to $24 \mathrm{~h}$ after admission were associated with a lower rate of progression to severe disease and 20 day mortality in both non-diabetic and diabetic hyperglycemic patients [50].

Poorly controlled hyperglycemia significantly increases the severity and mortality of patients with COVID-19, even after adjusting for multiple confounders (Table S3). The treating physician should assess the patient's glycemic status and achieve good glycemic control in patients, irrespective of pre-existing diabetes.

\section{Factors Associated with COVID-19-Related Hyperglycemia}

Worsening glycemic control during infections is common, especially in sepsis. Hyperglycemia induced by inflammation is a type of biological defense reaction against the acute stress of infectious diseases. It is known as stress hyperglycemia, which is usually defined as a transient hyperglycemic status associated with acute illness [51]. Stress hyperglycemia arises from a highly complex interplay between perturbed proinflammatory cytokines and insulin counter-regulatory hormones, which leads to the hyperproduction of hepatic glucose and the induction of insulin resistance. In addition to inflammation-induced insulin resistance, Sestan and colleagues demonstrated that virus-induced interferon- $\gamma$ increases muscle insulin resistance [52].

Moreover, the use of corticosteroids for treating patients with COVID-19 strongly contributes to hyperglycemia. Following the results of the RECOVERY clinical trial [53], systemic corticosteroids have become one of the main treatment choices for COVID-19; meanwhile, systemic corticosteroids are well known to induce hyperglycemia. The main mechanism for steroid-induced glucose dysregulation is thought to be the alteration of pancreatic $\beta$-cell function, promotion of glycogenolysis in the liver, and reduction of insulin sensitivity in the liver, skeletal muscle, and adipose tissue [54]. Additionally, reduced glucose uptake and increased glycogenolysis in skeletal muscle contribute to hyperglycemia [54]. Indeed, in a multicenter retrospective study of critically ill patients with COVID-19, researchers showed that the risk of hyperglycemia $(>7.8 \mathrm{mmol} / \mathrm{L}(>140 \mathrm{mg} / \mathrm{dL}))$ was significantly increased with the use of steroids (OR 1.521; 95\% CI 1.054-2.194) [55].

Even considering the hyperglycemia that occurs in response to acute stress or the use of glucocorticoids, the links between COVID-19 and hyperglycemia have been strongly suggested. The underlying pathogenesis of COVID-19-related hyperglycemia can be described by the damage to pancreatic $\beta$-cells and decreased insulin sensitivity and altered insulin secretion due to the activation of the renin-angiotensin system (RAS) and the host's inflammatory response to COVID-19. The details are described below.

\section{Effect of COVID-19 on Glucose Metabolism}

\subsection{Impaired Glucose Metabolism in COVID-19}

Angiotensin-converting enzyme II (ACE2) receptors are expressed in various human organs, including pancreatic $\beta$-cells, adipose tissue, the small intestine, and the kidneys [12,56]. SARS-CoV-2 can infect pancreatic tissue and cause acute pancreatic injury [57], which results in the dysregulation of glucose metabolism. In a human pluripotent stemcell-derived human cell and organoid model, Yang et al. found that SARS-CoV-2 infects pancreatic glucagon-positive $\alpha$-cells, insulin-positive $\beta$-cells, hepatocytes, and cholangio- 
cyte organoids [58]. Subsequently, Müller et al. showed that SARS-CoV-2 infects and replicates within the human islets of Langerhans, leading to impaired glucose-stimulated insulin secretion [59]. In addition to direct virus involvement, an enhanced autoimmune process might be implicated. Moreover, ACE2 plays an important role in regulating glucose homeostasis [60]. Downregulation of ACE2 by the entry of the virus can contribute to insulin resistance and insufficient insulin secretion through the RAS. The proinflammatory cytokines induced by COVID-19 also increase insulin resistance. Finally, hyperglycemia itself exacerbates $\beta$-cell dysfunction, leading to further poor glycemic control status.

\subsection{New-Onset Diabetes}

The development of virus-related diabetes is rare among natural viral infections; however, viral infections have long been suggested as potential environmental factors that trigger diabetes $[3,61]$. Particular viruses, such as enterovirus, especially coxsackievirus $B$ virus, rubella virus, cytomegalovirus, mumps [62], and SARS-CoV-1 [12], have been associated with $\beta$-cell destruction and the triggering of type 1 diabetes; moreover, the hepatitis $C$ virus has been implicated in inducing type 2 diabetes [63]. The putative pathogenic mechanisms of virus-related diabetes include direct $\beta$-cell destruction, local inflammatory responses, the triggering of autoimmunity against $\beta$-cells [62], and host genetic factors [64,65]. These potential mechanisms are yet to be fully studied.

There are case reports describing diabetic ketoacidosis (DKA) in a previously healthy man with no evidence of insulin resistance [66] and insulin-dependent diabetes presenting with DKA in the absence of autoantibodies 5-7 weeks after the COVID-19 episode [67]. A case series of hyper-glycemic emergencies from the United Kingdom found 2 cases with new presentation of diabetes among 35 COVID-19 patients; moreover, nine cases had type 2 diabetes among 11 patients presenting with DKA [68]. Two retrospective cohort studies in China identified patients with new-onset diabetes. In these studies, new-onset diabetes was defined as no prior history of diabetes with FPG $\geq 7.0 \mathrm{mmol} / \mathrm{L}$ [45] or random BG $>11.1 \mathrm{mmol} / \mathrm{L}[69]$ and $\mathrm{HbA} 1 \mathrm{c}<6.5 \%$; however, the type of diabetes was not reported. The prevalence of new-onset diabetes was 5.5\% [45] and 27.5\% [69] in 25 of 453 and 22 of 80 hospitalized COVID-19 patients, respectively.

A recent big data analysis based on medical claim databases in the United States observed that the individuals aged $<18$ years with COVID-19 were more likely to be newly diagnosed with diabetes in $>30$ days after infection than those without COVID-19 and those with non-SARS-CoV-2 respiratory infections [70]. Some multicenter studies found an increase in the incidence of pediatric type 1 diabetes and the frequency of severe DKA [71-73]. However, epidemiological evidence from European studies showed no clear increase in the incidence of type 1 diabetes during the COVID-19 pandemic [74-78]. Moreover, Hippich et al. revealed no association between SARS-CoV-2 antibodies and autoimmunity with type 1 diabetes [79].

It is unclear whether the phenotype of the new-onset diabetes triggered by COVID19 is the classic type 1 , or type 2, or a new type and whether its alterations of glucose metabolism are transient or persistent [10]. A global registry of patients with COVID-19related new-onset diabetes has been established (CoviDIAB Project, covidiab.e-dendrite.com) to investigate the epidemiological features and pathogenesis [10].

The expression of ACE2 in human pancreatic $\beta$ cells is controversial $[58,80,81]$, and the direct cell dysfunction cannot fully explain a key pathogenic mechanism of SARS-CoV-2 infection-induced diabetes. In COVID-19 patients, insulin resistance seems to be abnormal when compared to patients with other critical conditions [82]. This could be a factor affecting the process of new-onset hyperglycemia or diabetes in COVID-19. Montefusco and colleagues demonstrated hyperglycemia and insulin resistance in COVID-19 patients without diabetes [83]. The persistence of hyperglycemia [83] and insulin resistance [84] were documented six months after acute COVID-19 infections. Furthermore, regarding glucose homeostasis in patients with coronavirus infection, the gut is less focused than pancreas, liver, skeletal muscle, and adipose tissue. However, increased intestinal glucose absorption 
via the sodium-dependent glucose transporter (SGLT1) in the intestinal epithelium, which is mediated by the downregulation of ACE2 with a SARS-CoV-2 infection, might also be involved in hyperglycemia in COVID-19 patients [85].

Assessing the diabetogenic and ketosis-prone potential of SARS-CoV-2 variants is an additional challenge. The pandemic variants of SARS-CoV-2 have been reported to change the viral characteristics, including the transmissibility and antigenicity (summarized in Table 1). However, most of the currently available data were based on studies conducted before the major variants of SARS-CoV-2 were circulated. The Omicron variant is associated with a more attenuated disease severity compared to previous circulating variants [86,87]. Its cellular entry is reported to be less dependent on TMPRSS2 [88]. Replication is reduced in the lower respiratory tract that highly expresses TMPRSS2, whereas the infectivity of the Omicron variant is not affected in non-TMPRSS2-expressing cells in the upper respiratory tract [88]. Moreover, the Omicron variant is characterized by a higher ACE2 binding affinity and increased immune evasion [88,89]. The expressions of ACE2 and TMPRSS2 under steady state conditions have different distributions $[58,80,90]$. The tissue tropism of variants and their impact on glycometabolism might be affected.

Table 1. Comparison of the characteristics of pandemic SARS-CoV-2 variants.

\begin{tabular}{|c|c|c|c|}
\hline WHO Label & Alpha & Delta & Omicron \\
\hline Pango Lineage & B.1.1.7, Q & B.1.617.2, AY.4.2 & B.1.1.529, BA \\
\hline \multirow{2}{*}{ First detected } & United Kingdom & India & South Africa \\
\hline & September 2020 & December 2020 & November 2021 \\
\hline $\begin{array}{l}\text { Key amino acid } \\
\text { substitutions in } \\
\text { spike protein }\end{array}$ & N501Y, D614G, and P681H & $\begin{array}{c}\text { L452R, T478K, D614G, } \\
\text { and P681R }\end{array}$ & $\begin{array}{l}30 \text { changes, } 3 \text { small deletions, } \\
\text { and } 1 \text { small insertion * }\end{array}$ \\
\hline \multirow[b]{2}{*}{ Infectivity Transmissibility } & $\uparrow$ & $\uparrow \sim \uparrow \uparrow$ & $\uparrow \uparrow \uparrow$ \\
\hline & $\begin{array}{l}43-82 \% \text { more transmissible } \\
\text { than the ancestral lineage }\end{array}$ & At least equal to alpha & $\begin{array}{c}\mathrm{Rt}_{\text {Omicron }}{ }^{3.19-4.2} \text { times } \\
\text { greater than } \mathrm{Rt}_{\text {Delta }}, \text { with } \\
\text { higher secondary attack rates }\end{array}$ \\
\hline Clinical severity & $\begin{array}{l}\rightarrow / \uparrow \\
\text { 60\% higher mortality than the } \\
\text { ancestral lineage }\end{array}$ & $\begin{array}{c}\uparrow \uparrow \\
\text { risk for hospital admission } \\
\text { twice as high as alpha }\end{array}$ & $\begin{array}{l}\downarrow \\
\text { Decrease in severity } \\
\text { and mortality }\end{array}$ \\
\hline Immune escape & $\rightarrow$ & \multicolumn{2}{|c|}{ Higher reinfection rate and reduced vaccine efficacy } \\
\hline Diabetogenecity & Insufficient data ** & No data & No data \\
\hline & $\begin{array}{l}{ }^{*} \text { A67V, del69-70, T95I, del142-144, Y } \\
\text { G446S, S477N, T478K, E484A, Q493 } \\
\text { N764K, D796Y, N856K, Q954H, N96 } \\
\text { Rt: effective reproduction number. } \\
\text { when the alpha variant was domina } \\
\text { rate [97], severity }[86,92,98,99] \text {, reinfe }\end{array}$ & $\begin{array}{l}\text { D, del211, L212I, ins214EPE, G33 } \\
\text { G496S, Q498R, N501Y, Y505H, } \\
\text { and L981F (RBD substitutions ir } \\
\text { tudy supporting new-onset diabe } \\
\text { References: [91], transmissibility } \\
\text { on [100], and immune escape [89. }\end{array}$ & $\begin{array}{l}\text { S371L, S373P, S375F, K417N, N440K, } \\
7 \mathrm{~K}, \mathrm{D} 614 \mathrm{G}, \mathrm{H} 655 \mathrm{Y}, \mathrm{N} 679 \mathrm{~K}, \mathrm{P} 681 \mathrm{H}, \\
\text { old type). } \uparrow: \text { increased; } \downarrow \text { : decreased; } \\
\text { [70] included data during the period } \\
2-94], \text { Rt }[95,96] \text {, secondary infection }\end{array}$ \\
\hline
\end{tabular}

\section{Mechanism of Disease Aggravation in Diabetes}

\subsection{Altered Host Immune Response in the Diabetic Host}

In people with diabetes, dysfunctional immune responses appear to contribute to disease progression in COVID-19. In these individuals, innate immunity is impaired, including the capacity for chemotaxis, migratory response, and phagocytosis [11]. Both type 1 and type 2 diabetes result in altered cytokine secretion and low-grade systemic inflammation status [101]. Natural killer cell activity is reduced in type 2 diabetes, in association with glucose control [102]. As for adaptive immunity, the humoral immune response is relatively normal, whereas the cell-mediated immune response is involved. Abnormal T-cell differentiation has been reported in patients with type 2 diabetes. Jagannathan-Bogdan et al. demonstrated a elevations in the Th17 subpopulation and in IL-17 and interferon- $\gamma$ production, which is supported by monocytes, using human peripheral blood samples [103]. Deceased numbers of Th2 and Treg cells are reported to feature in diabetes [104]. In addi- 
tion to the evidence provided by the analysis of peripheral blood mononuclear cells, Tang et al. demonstrated in a non-obese diabetic mouse model that CD4+ Foxp3+ regulatory $\mathrm{T}$ cells were decreased in inflamed islets during the progression of type 1 diabetes [105]. Taken together, $\mathrm{T}$ cells are naturally skewed toward the proinflammatory phenotype in individuals with diabetes. This status potentially exacerbates hyperinflammation, resulting in a loss of homeostasis in the inflammatory response.

In the context of COVID-19, after the recognition of SARS-CoV2 entry, proinflammatory cytokines and chemokines are generated. These attract monocytes, macrophages, and $\mathrm{T}$ cells to the infection site, which leads to further inflammation. In a healthy immune response, the initial inflammation, followed by the virus-specific T-cell attraction and production of neutralizing antibodies, leads to clearance of the virus before viral spreading and minimal lung damage. However, in a defective immune response, the accumulation of immune cells in the lungs, which causes an overproduction of proinflammatory cytokines, results in lung and multiorgan damage [106].

\subsection{Role of the Renin-Angiotensin Aldosterone System}

Zhou et al. [107] and Hoffmann et al. [108] identified ACE2 as a functional receptor of SARS-CoV-2. This is the same cell receptor for SARS- CoV-1 [109]. Moreover, Hoffmann et al. showed that receptor-mediated virus entry depends on cellular serine protease transmembrane serine protease 2 (TMPRSS2), which primes the spike protein. ACE2 is a membrane protein that cleaves angiotensin 2 (Ang-II) and generates angiotensin (1-7), exerting a negative effect on Ang-II signaling. Ang-II acts not only toward vasoconstriction but also toward proinflammation via the angiotensin type 1 receptor (AT1R) [110]. Meanwhile, Ang (1-7) acts toward anti-inflammation by binding to and activating the Mas receptor. After the virus binds to ACE2, ACE2 is endocytosed together with the virus complex, which reduces ACE2 expression on the cell surface, resulting in Ang-II accumulation and a decreased effect of the ACE2/Ang-(1-7)/MasR axis. This competing effect of two axes could lead to acute lung injury, cytokine storm, and ARDS [111].

In a non-obese diabetic mouse model, ACE was found to be highly expressed in the lungs, whereas ACE2 was highly expressed in the pancreas [112]. A microarray analysis revealed the upregulation of ACE2 in human pancreatic islets from diabetic donors [113]. From these results, the change of these expression levels might contribute to the increasing lung damage and $\beta$-cell tropism in diabetic patients with COVID-19, although the clinical implications remain to be established.

\subsection{Other Host Factors}

Other possible factors that increase the severity of COVID-19 in diabetes include endothelial dysfunction $[114,115]$, a hypercoagulative state $[115,116]$, and alveolar dysfunction [117]. Hyperglycemia enhances coagulation during systemic inflammation [118]. Varga et al. found direct endothelial cell infection by SARS-CoV-2 and subsequent endothelitis, resulting in a hypercoagulable state [119]. This might be linked to the increase in the incidence of thrombotic events during COVID-19. Alveolar dysfunction may contribute to a very low tolerance for lung damage, leading to an increased oxygen requirement.

\subsection{Factors Affecting Viral Replication}

Codo et al. demonstrated one of the mechanisms by which people with uncontrolled hyperglycemia develop a severe form of COVID-19. In human monocytes, elevated glucose levels can directly promote SARS-CoV-2 replication, the production of proinflammatory cytokines, and subsequent T-cell dysfunction and lung epithelial cell death via the production of mitochondrial reactive oxygen species and hypoxia-inducible factor- $1 \alpha$ (HIF- $1 \alpha$ ) stabilization. SARS-CoV-2 promotes the transition to aerobic glycolysis in monocyte metabolism, which sustains the SARS-CoV-2-induced monocyte response and viral replication [120]. However, Wing et al. reported the negative effect of HIF signaling on SARS-CoV-2. In lung epithelial cells, HIF activation reduces the expression of ACE2 and TMPRSS2 and inhibits 
SARS-CoV-2 entry. Additionally, it inhibits viral replication and the secretion of infectious particles in an HIF-1 $\alpha$-dependent manner [121]. Further studies are needed to determine the role of the HIF- $1 \alpha$ pathway and in vivo behavior.

\section{Treatment of COVID-19 in Diabetes}

Current treatment options for COVID-19 are divided into antiviral agents (e.g., remdesivir), monoclonal antibodies (e.g., casirivimab plus imdevimab and sotrovimab), immunomodulators (e.g., dexamethasone, baricitinib, and tosirizumab), and anticoagulant therapy. Recently, molnupiravir was approved as the first oral antiviral medicine for adult patients with mild-to-moderate COVID-19 and at least one risk factor associated with poor disease outcomes. Although there is no definitive therapy, these drugs are sometimes used in combination according to disease severity, oxygen requirements, and hospitalization in clinical practice. Basically, antiviral agents and monoclonal antibodies are administered against viral replication in the early stage, and anti-inflammatory drugs are administered against a dysregulated host immune response in the later stage [122].

Although there is no specific treatment for COVID-19 in patients with diabetes, prompt intervention is required because these patients are at a high risk of COVID-19 clinical progression. In Japan, monoclonal antibodies are recommended for administration as soon as possible after diagnosis to reduce the risk of hospitalization and death in patients with mild-to-moderate COVID-19 who have certain risk factors for disease progression. These risk factors include age $\geq 65$ years, diabetes, obesity (BMI $>30 \mathrm{~kg} / \mathrm{m}^{2}$ ), cardiovascular disease or hypertension, and chronic lung diseases (National Institutes of Health COVID-19 Treatment Guideline. Available online: https: / / www.covid19treatmentguidelines.nih.gov (accessed on 7 December 2021)). Further studies are needed to determine whether the use of monoclonal antibodies can improve the prognosis in diabetes. The reduction in the neutralization efficacy of imdevimab and casirivimab against the Omicron variant has been reported [89], and it is necessary to obtain up-to-date information about the epidemic variant before initiating monoclonal antibody treatment. Dexamethasone has a potential anti-inflammatory action that can prevent or suppress these excessive inflammatory responses in COVID-19, and it has been reported to have benefits for patients who received supplemental oxygen [53]. Dexamethasone should be used with more attention to glycemic control, irrespective of the diabetes status [123]. Oral Janus kinase inhibitors or anti-IL-6 receptor monoclonal antibodies might be effective for improving clinical outcomes in more severe cases. Such anti-inflammatory therapy can have negative effects on viral elimination in the host defense; therefore, it is important to assess the state of COVID-19 patients and optimize the timing of administration and drug type in high-risk patients.

Although there is no consensus on the use or discontinuation of certain antihyperglycemic agents, patients should maintain good glycemic control. A few anti-diabetic agents have been shown to influence ACE2 expressions in animal models [112,124-126]. Moreover, several agents not only have glucose-lowering effects but also have pleiotropic anti-inflammatory actions [127-131], which attract attention due to their potential beneficial roles in SARS-CoV-2 infections. However, no conclusive data demonstrate clinically significant differences (Table 2). Great caution is required when considering the possible risks resulting from lactic acidosis due to metformin as well as euglycemic diabetic ketoacidosis and dehydration due to sodium-glucose-co-transporter 2 inhibitors.

Hence, it is extremely important for people with diabetes to take steps to prevent infection, such as using hand hygiene, wearing a mask, and avoiding contact with COVID19 patients. Vaccination against SARS-CoV-2 is recommended and can be effective in people with diabetes, as supported by the data showing no difference in humoral immune response against SARS-CoV-2 in patients with or without diabetes [132,133]. 
Table 2. Potential roles of antidiabetic agents and related clinical data in COVID-19 patients.

\begin{tabular}{|c|c|c|c|c|}
\hline Antidiabetic Agent & $\begin{array}{c}\text { Effects on ACE2 Expression in } \\
\text { Animal Models }\end{array}$ & Anti-Inflammatory Properties & $\begin{array}{l}\text { Data from Clinical Studies on } \\
\text { COVID-19 }\end{array}$ & Clinical Considerations \\
\hline Metformin & 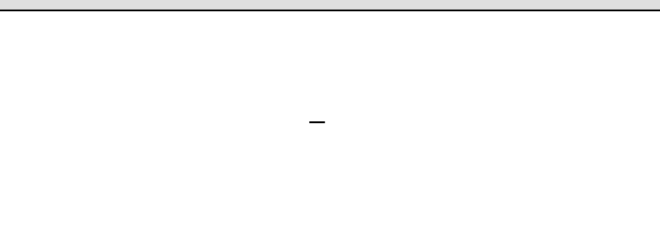 & $+[127]$ & $\begin{array}{c}\text { No association }[134,135] \\
\text { Lower incidence of COVID-19 and } \\
\text { no effects on mortality [136] } \\
\text { Improved outcomes [137] } \\
\text { Reduced mortality }[27,138,139] \\
\text { only in women }[140]\end{array}$ & $\begin{array}{l}\text { Risk of lactic acidosis } \\
\text { Discontinued in severe cases }\end{array}$ \\
\hline Pioglitazone & $\begin{array}{l}\text { Upregulation of ACE2 expressions in the } \\
\text { liver, adipose tissues, and skeletal muscles } \\
\text { in NASH rats [124] }\end{array}$ & $+[128]$ & Insufficient evidence & $\begin{array}{l}\text { Risk of fluid retention and heart failure } \\
\text { Discontinued in severe cases }\end{array}$ \\
\hline SGLT2 inhibitors & - & $+[129]$ & $\begin{array}{c}\text { No influence on susceptibility } \\
\text { compared with DPP-4 inhibitors } \\
{[141]}\end{array}$ & $\begin{array}{c}\text { Risk of euglycemic diabetic ketoacidosis } \\
\text { and dehydration } \\
\text { Discontinued in severe cases }\end{array}$ \\
\hline GLP1-RAs & $\begin{array}{l}\text { Upregulation of ACE2 expression in lungs } \\
\text { in STZ-induced diabetic rats [125] }\end{array}$ & $+[129,130]$ & Insufficient evidence & $\begin{array}{l}\text { Risk of dehydration in cases with severe } \\
\text { gastrointestinal symptoms }\end{array}$ \\
\hline DPP-4 inhibitors & - & $+[130,131]$ & $\begin{array}{c}\text { Not associated with adverse } \\
\text { outcomes [134,142-144] } \\
\text { Lower mortality [145,146] } \\
\text { Improved outcomes [146] } \\
\text { Worse outcome [147] }\end{array}$ & Relatively safe \\
\hline Insulin & $\begin{array}{l}\text { Normalization of renal ADAM17 and } \\
\text { ACE2 expressions in diabetic Akita mice [126] } \\
\text { Increased ACE2/ACE in NOD mice [112] }\end{array}$ & $\begin{array}{l}\text { +; reduced inflammatory } \\
\text { marker [148] }\end{array}$ & $\begin{array}{c}\text { Poor prognosis }[149] \\
\text { Increased mortality }[27,137,145,150] \\
\text { No association }[134,139] \\
\text { Beneficial effects of control during } \\
\text { hospitalization }[49]\end{array}$ & $\begin{array}{l}\text { Risk of hypoglycemia } \\
\text { Require frequent blood glucose } \\
\text { monitoring }\end{array}$ \\
\hline
\end{tabular}




\section{Conclusions}

We are amidst dual pandemics of COVID-19 and diabetes and face the threat of the emergence of SARS-CoV-2 variants, including the Omicron variant. These are intricately interrelated, and it is particularly important to reveal the precise mechanism underlying the association between COVID-19 and diabetes as well as to dissolve the vicious circle of hyperinflammation and hyperglycemia. The incidence and etiology of new-onset diabetes remain to be fully elucidated, and the diabetogenic properties of SARS-CoV-2 depending on the variants is a subject for future investigation.

Supplementary Materials: The following supporting information can be downloaded at: https:// www.mdpi.com/article/10.3390/biology11030400/s1, Table S1: Overview of the risk for COVID-19related mortality according to the glycemic control status before hospitalization; Table S2: Overview of the risk for adverse clinical outcomes of COVID-19 according to the blood glucose levels at admission; Table S3: Overview of the risk for adverse clinical outcomes of COVID-19 according to the glycemic control during hospitalization.

Author Contributions: Conceptualization, A.Y. and N.S.; writing-original draft preparation, writing -review and editing, A.Y.; supervision, N.S. All authors have read and agreed to the published version of the manuscript.

Funding: This research received no external funding.

Institutional Review Board Statement: Not applicable.

Informed Consent Statement: Not applicable.

Data Availability Statement: Not applicable.

Acknowledgments: We sincerely thank all members of our departments for helpful discussion and comments in the clinical practice of COVID-19.

Conflicts of Interest: The authors declare no conflict of interest.

\section{References}

1. Morens, D.M.; Daszak, P.; Markel, H.; Taubenberger, J.K. Pandemic COVID-19 Joins History's Pandemic Legion. mBio 2020, 11, 11. [CrossRef]

2. Saeedi, P.; Petersohn, I.; Salpea, P.; Malanda, B.; Karuranga, S.; Unwin, N.; Colagiuri, S.; Guariguata, L.; Motala, A.A.; Ogurtsova, K.; et al. Diabetes Atlas Committee. Global and Regional Diabetes Prevalence Estimates for 2019 and Projections for 2030 and 2045: Results from the International Diabetes Federation Diabetes Atlas. Diabetes Res. Clin. Pract. 2019, 157, 107843. [CrossRef] [PubMed]

3. American Diabetes Association. 2. Classification and Diagnosis of Diabetes: Standards of Medical Care in Diabetes-2021. Diabetes Care 2021, 44 (Suppl. 1), S15-S33. [CrossRef] [PubMed]

4. Carey, I.M.; Critchley, J.A.; DeWilde, S.; Harris, T.; Hosking, F.J.; Cook, D.G. Risk of Infection in Type 1 and Type 2 Diabetes Compared with the General Population: A Matched Cohort Study. Diabetes Care 2018, 41, 513-521. [CrossRef] [PubMed]

5. Critchley, J.A.; Carey, I.M.; Harris, T.; DeWilde, S.; Hosking, F.J.; Cook, D.G. Glycemic Control and Risk of Infections among People with Type 1 or Type 2 Diabetes in a Large Primary Care Cohort Study. Diabetes Care 2018, 41, 2127-2135. [CrossRef]

6. Wu, Z.; McGoogan, J.M. Characteristics of and Important Lessons from the Coronavirus Disease 2019 (COVID-19) Outbreak in China: Summary of a Report of 72314 Cases from the Chinese Center for Disease Control and Prevention. JAMA 2020, 323, 1239-1242. [CrossRef] [PubMed]

7. Barron, E.; Bakhai, C.; Kar, P.; Weaver, A.; Bradley, D.; Ismail, H.; Knighton, P.; Holman, N.; Khunti, K.; Sattar, N.; et al. Associations of Type 1 and Type 2 Diabetes with COVID-19-Related Mortality in England: A Whole-Population Study. Lancet Diabetes Endocrinol. 2020, 8, 813-822. [CrossRef]

8. McGurnaghan, S.J.; Weir, A.; Bishop, J.; Kennedy, S.; Blackbourn, L.A.K.; A McAllister, D.; Hutchinson, S.; Caparrotta, T.M.; Mellor, J.; Jeyam, A.; et al. Risks of and Risk Factors for COVID-19 Disease in People with Diabetes: A Cohort Study of the Total Population of Scotland. Lancet Diabetes Endocrinol. 2021, 9, 82-93. [CrossRef]

9. Gregory, J.M.; Slaughter, J.C.; Duffus, S.H.; Smith, T.J.; LeStourgeon, L.M.; Jaser, S.S.; McCoy, A.B.; Luther, J.M.; Giovannetti, E.R.; Boeder, S.; et al. COVID-19 Severity Is Tripled in the Diabetes Community: A Prospective Analysis of the Pandemic's Impact in Type 1 and Type 2 Diabetes. Diabetes Care 2021, 44, 526-532. [CrossRef] [PubMed]

10. Rubino, F.; Amiel, S.A.; Zimmet, P.; Alberti, G.; Bornstein, S.; Eckel, R.H.; Mingrone, G.; Boehm, B.; Cooper, M.E.; Chai, Z.; et al. New-Onset Diabetes in COVID-19. N. Engl. J. Med. 2020, 383, 789-790. [CrossRef] [PubMed] 
11. Casqueiro, J.; Casqueiro, J.; Alves, C. Infections in Patients with Diabetes Mellitus: A Review of Pathogenesis. Indian J. Endocrinol. Metab. 2012, 16, S27-S36. [PubMed]

12. Yang, J.K.; Lin, S.S.; Ji, X.J.; Guo, L.M. Binding of Sars Coronavirus to Its Receptor Damages Islets and Causes Acute Diabetes. Acta Diabetol. 2010, 47, 193-199. [CrossRef] [PubMed]

13. Yang, J.K.; Feng, Y.; Yuan, M.Y.; Yuan, S.Y.; Fu, H.J.; Wu, B.Y.; Sun, G.Z.; Yang, G.R.; Zhang, X.L.; Wang, L.; et al. Plasma Glucose Levels and Diabetes Are Independent Predictors for Mortality and Morbidity in Patients with Sars. Diabet. Med. 2006, 23, 623-628. [CrossRef]

14. Allard, R.; Leclerc, C.; Tremblay, P.; Tannenbaum, T.N. Diabetes and the Severity of Pandemic Influenza a (H1n1) Infection. Diabetes Care 2010, 33, 1491-1493. [CrossRef] [PubMed]

15. Richardson, S.; Hirsch, J.S.; Narasimhan, M.; Crawford, J.M.; McGinn, T.; Davidson, K.W.; Barnaby, D.P.; Becker, L.B.; Chelico, J.D.; Cohen, S.L.; et al. Presenting Characteristics, Comorbidities, and Outcomes among 5700 Patients Hospitalized with COVID-19 in the New York City Area. JAMA 2020, 323, 2052-2059. [CrossRef] [PubMed]

16. Al-Salameh, A.; Lanoix, J.P.; Bennis, Y.; Andrejak, C.; Brochot, E.; Deschasse, G.; Dupont, H.; Goeb, V.; Jaureguy, M.; Lion, S.; et al. Characteristics and Outcomes of COVID-19 in Hospitalized Patients with and without Diabetes. Diabetes Metab. Res. Rev. 2021, 37, e3388. [CrossRef]

17. Zhang, Y.; Cui, Y.; Shen, M.; Zhang, J.; Liu, B.; Dai, M.; Chen, L.; Han, D.; Fan, Y.; Zeng, Y.; et al. Association of Diabetes Mellitus with Disease Severity and Prognosis in COVID-19: A Retrospective Cohort Study. Diabetes Res. Clin. Pract. 2020, $165,108227$. [CrossRef] [PubMed]

18. Zhou, F.; Yu, T.; Du, R.; Fan, G.; Liu, Y.; Liu, Z.; Xiang, J.; Wang, Y.; Song, B.; Gu, X.; et al. Clinical Course and Risk Factors for Mortality of Adult Inpatients with COVID-19 in Wuhan, China: A Retrospective Cohort Study. Lancet 2020, 395, 1054-1062. [CrossRef]

19. Petrilli, C.M.; Jones, S.A.; Yang, J.; Rajagopalan, H.; O’Donnell, L.; Chernyak, Y.; Tobin, K.A.; Cerfolio, R.J.; Francois, F.; Horwitz, L.I. Factors Associated with Hospital Admission and Critical Illness among 5279 People with Coronavirus Disease 2019 in New York City: Prospective Cohort Study. BMJ 2020, 369, m1966. [CrossRef] [PubMed]

20. Team, C. COVID-Response. Preliminary Estimates of the Prevalence of Selected Underlying Health Conditions among Patients with Coronavirus Disease 2019-United States, February 12-March 28, 2020. MMWR Morb. Mortal. Wkly. Rep. 2020, 69, $382-386$.

21. Matsunaga, N.; Hayakawa, K.; Terada, M.; Ohtsu, H.; Asai, Y.; Tsuzuki, S.; Suzuki, S.; Toyoda, A.; Suzuki, K.; Endo, M.; et al Clinical Epidemiology of Hospitalized Patients with COVID-19 in Japan: Report of the COVID-19 Registry Japan. Clin. Infect. Dis. 2020, 11, e3677-e3689.

22. Pugliese, G.; Vitale, M.; Resi, V.; Orsi, E. Is Diabetes Mellitus a Risk Factor for Coronavirus Disease 19 (COVID-19)? Acta Diabetol. 2020, 57, 1275-1285. [CrossRef]

23. Gregory, J.M.; Moore, D.J. The Dual Burden of Type 1 Diabetes and COVID-19. Ann. Intern. Med. 2021, 174, 703-704. [CrossRef] [PubMed]

24. Lighter, J.; Phillips, M.; Hochman, S.; Sterling, S.; Johnson, D.; Francois, F.; Stachel, A. Obesity in Patients Younger Than 60 Years Is a Risk Factor for COVID-19 Hospital Admission. Clin. Infect. Dis. 2020, 71, 896-897. [CrossRef] [PubMed]

25. Simonnet, A.; Chetboun, M.; Poissy, J.; Raverdy, V.; Noulette, J.; Duhamel, A.; Labreuche, J.; Mathieu, D.; Pattou, F.; Jourdain, M. Licorn, COVID the Lille, and group Obesity study. High Prevalence of Obesity in Severe Acute Respiratory Syndrome Coronavirus-2 (SARS-CoV-2) Requiring Invasive Mechanical Ventilation. Obes. (Silver Spring) 2020, 28, 1195-1199. [CrossRef]

26. Holman, N.; Knighton, P.; Kar, P.; O’Keefe, J.; Curley, M.; Weaver, A.; Barron, E.; Bakhai, C.; Khunti, K.; Wareham, N.J.; et al. Risk Factors for COVID-19-Related Mortality in People with Type 1 and Type 2 Diabetes in England: A Population-Based Cohort Study. Lancet Diabetes Endocrinol. 2020, 8, 823-833. [CrossRef]

27. Cariou, B.; Hadjadj, S.; Wargny, M.; Pichelin, M.; Al-Salameh, A.; Allix, I.; Amadou, C.; Arnault, G.; Baudoux, F.; Bauduceau, B.; et al. Phenotypic Characteristics and Prognosis of Inpatients with COVID-19 and Diabetes: The Coronado Study. Diabetologia 2020, 63, 1500-1515. [CrossRef] [PubMed]

28. Smati, S.; Tramunt, B.; Wargny, M.; Caussy, C.; Gaborit, B.; Vatier, C.; Verges, B.; Ancelle, D.; Amadou, C.; Bachir, L.A.; et al. Relationship between Obesity and Severe COVID-19 Outcomes in Patients with Type 2 Diabetes: Results from the Coronado Study. Diabetes Obes. Metab. 2021, 23, 391-403. [CrossRef] [PubMed]

29. Blaszczak, A.M.; Jalilvand, A.; Hsueh, W.A. Adipocytes, Innate Immunity and Obesity: A Mini-Review. Front. Immunol. 2021, 12, 650768. [CrossRef] [PubMed]

30. Melo, L.C.; MSilva, A.; Calles, A.C. Obesity and Lung Function: A Systematic Review. Einstein (Sao Paulo) 2014, 12, 120-125. [CrossRef]

31. Lu, X.; Cui, Z.; Pan, F.; Li, L.; Li, L.; Liang, B.; Yang, L.; Zheng, C. Glycemic Status Affects the Severity of Coronavirus Disease 2019 in Patients with Diabetes Mellitus: An Observational Study of Ct Radiological Manifestations Using an Artificial Intelligence Algorithm. Acta Diabetol. 2021, 58, 575-586. [CrossRef] [PubMed]

32. Williamson, E.J.; Walker, A.J.; Bhaskaran, K.; Bacon, S.; Bates, C.; Morton, C.E.; Curtis, H.J.; Mehrkar, A.; Evans, D.; Inglesby, P.; et al. Factors Associated with COVID-19-Related Death Using Opensafely. Nature 2020, 584, 430-436. [CrossRef] [PubMed]

33. Iacobellis, G.; Penaherrera, C.A.; Bermudez, L.E.; Mizrachi, E.B. Admission Hyperglycemia and Radiological Findings of SARS-CoV2 in Patients with and without Diabetes. Diabetes Res. Clin. Pract. 2020, 164, 108185. [CrossRef] [PubMed] 
34. Wang, S.; Ma, P.; Zhang, S.; Song, S.; Wang, Z.; Ma, Y.; Xu, J.; Wu, F.; Duan, L.; Yin, Z.; et al. Fasting Blood Glucose at Admission Is an Independent Predictor for 28-Day Mortality in Patients with COVID-19 without Previous Diagnosis of Diabetes: A Multi-Centre Retrospective Study. Diabetologia 2020, 63, 2102-2111. [CrossRef]

35. Yang, P.; Wang, N.; Wang, J.; Luo, A.; Gao, F.; Tu, Y. Admission Fasting Plasma Glucose Is an Independent Risk Factor for 28-Day Mortality in Patients with COVID-19. J. Med. Virol. 2021, 93, 2168-2176. [CrossRef] [PubMed]

36. Zhang, J.; Kong, W.; Xia, P.; Xu, Y.; Li, L.; Li, Q.; Yang, L.; Wei, Q.; Wang, H.; Li, H.; et al. Impaired Fasting Glucose and Diabetes Are Related to Higher Risks of Complications and Mortality among Patients with Coronavirus Disease 2019. Front. Endocrinol. (Lausanne) 2020, 11, 525. [CrossRef] [PubMed]

37. Liu, S.P.; Zhang, Q.; Wang, W.; Zhang, M.; Liu, C.; Xiao, X.; Liu, Z.; Hu, W.M.; Jin, P. Hyperglycemia Is a Strong Predictor of Poor Prognosis in COVID-19. Diabetes Res. Clin. Pract. 2020, 167, 108338. [CrossRef] [PubMed]

38. Wu, J.; Huang, J.; Zhu, G.; Wang, Q.; Lv, Q.; Huang, Y.; Yu, Y.; Si, X.; Yi, H.; Wang, C.; et al. Elevation of Blood Glucose Level Predicts Worse Outcomes in Hospitalized Patients with COVID-19: A Retrospective Cohort Study. BMJ Open Diabetes Res. Care 2020, 8, e001476. [CrossRef] [PubMed]

39. Liu, Q.; Chen, H.; Li, J.; Huang, X.; Lai, L.; Li, S.; Zeng, Q. Fasting Blood Glucose Predicts the Occurrence of Critical Illness in COVID-19 Patients: A Multicenter Retrospective Cohort Study. J. Infect. 2020, 81, e20-e23. [CrossRef] [PubMed]

40. Fadini, G.P.; Morieri, M.L.; Boscari, F.; Fioretto, P.; Maran, A.; Busetto, L.; Bonora, B.M.; Selmin, E.; Arcidiacono, G.; Pinelli, S.; et al. Newly-Diagnosed Diabetes and Admission Hyperglycemia Predict COVID-19 Severity by Aggravating Respiratory Deterioration. Diabetes Res. Clin. Pract. 2020, 168, 108374. [CrossRef]

41. Smith, S.M.; Boppana, A.; Traupman, J.A.; Unson, E.; Maddock, D.A.; Chao, K.; Dobesh, D.P.; Brufsky, A.; Connor, R.I. Impaired Glucose Metabolism in Patients with Diabetes, Prediabetes, and Obesity Is Associated with Severe COVID-19. J. Med. Virol. 2021, 93, 409-415. [CrossRef] [PubMed]

42. Zhang, Y.; Li, H.; Zhang, J.; Cao, Y.; Zhao, X.; Yu, N.; Gao, Y.; Ma, J.; Zhang, H.; Zhang, J.; et al. The Clinical Characteristics and Outcomes of Patients with Diabetes and Secondary Hyperglycaemia with Coronavirus Disease 2019: A Single-Centre, Retrospective, Observational Study in Wuhan. Diabetes Obes. Metab. 2020, 22, 1443-1454. [CrossRef] [PubMed]

43. Li, Y.; Han, X.; Alwalid, O.; Cui, Y.; Cao, Y.; Liu, J.; Gu, J.; Wang, L.; Fan, Y.; Shi, H. Baseline Characteristics and Risk Factors for Short-Term Outcomes in 132 COVID-19 Patients with Diabetes in Wuhan China: A Retrospective Study. Diabetes Res. Clin. Pract. 2020, 166, 108299. [CrossRef]

44. Klonoff, D.C.; Messler, J.C.; Umpierrez, G.E.; Peng, L.; Booth, R.; Crowe, J.; Garrett, V.; McFarland, R.; Pasquel, F.J. Association between Achieving Inpatient Glycemic Control and Clinical Outcomes in Hospitalized Patients with COVID-19: A Multicenter, Retrospective Hospital-Based Analysis. Diabetes Care 2021, 44, 578-585. [CrossRef] [PubMed]

45. Li, H.; Tian, S.; Chen, T.; Cui, Z.; Shi, N.; Zhong, X.; Qiu, K.; Zhang, J.; Zeng, T.; Chen, L.; et al. Newly Diagnosed Diabetes Is Associated with a Higher Risk of Mortality Than Known Diabetes in Hospitalized Patients with COVID-19. Diabetes Obes. Metab. 2020, 22, 1897-1906. [CrossRef] [PubMed]

46. Coppelli, A.; Giannarelli, R.; Aragona, M.; Penno, G.; Falcone, M.; Tiseo, G.; Ghiadoni, L.; Barbieri, G.; Monzani, F.; Virdis, A.; et al. Hyperglycemia at Hospital Admission Is Associated with Severity of the Prognosis in Patients Hospitalized for COVID-19: The Pisa COVID-19 Study. Diabetes Care 2020, 43, 2345-2348. [CrossRef] [PubMed]

47. Bode, B.; Garrett, V.; Messler, J.; McFarland, R.; Crowe, J.; Booth, R.; Klonoff, D.C. Glycemic Characteristics and Clinical Outcomes of COVID-19 Patients Hospitalized in the United States. J. Diabetes Sci. Technol. 2020, 14, 813-821. [CrossRef]

48. Zhu, L.; She, Z.G.; Cheng, X.; Qin, J.J.; Zhang, X.J.; Cai, J.; Lei, F.; Wang, H.; Xie, J.; Wang, W.; et al. Association of Blood Glucose Control and Outcomes in Patients with COVID-19 and Pre-Existing Type 2 Diabetes. Cell Metab. 2020, 31, 1068-1077.e3. [CrossRef] [PubMed]

49. Sardu, C.; D'Onofrio, N.; Balestrieri, M.L.; Barbieri, M.; Rizzo, M.R.; Messina, V.; Maggi, P.; Coppola, N.; Paolisso, G.; Marfella, R. Outcomes in Patients with Hyperglycemia Affected by COVID-19: Can We Do More on Glycemic Control? Diabetes Care 2020, 43, 1408-1415. [CrossRef] [PubMed]

50. Sardu, C.; D'Onofrio, N.; Balestrieri, M.L.; Barbieri, M.; Rizzo, M.R.; Messina, V.; Maggi, P.; Coppola, N.; Paolisso, G.; Marfella, R. Hyperglycaemia on Admission to Hospital and COVID-19. Diabetologia 2020, 63, 2486-2487. [CrossRef] [PubMed]

51. Dungan, K.M.; Braithwaite, S.S.; Preiser, J.C. Stress Hyperglycaemia. Lancet 2009, 373, 1798-1807. [CrossRef]

52. Sestan, M.; Marinovic, S.; Kavazovic, I.; Cekinovic, D.; Wueest, S.; Wensveen, T.T.; Brizic, I.; Jonjic, S.; Konrad, D.; Wensveen, F.M.; et al. Virus-Induced Interferon-Gamma Causes Insulin Resistance in Skeletal Muscle and Derails Glycemic Control in Obesity. Immunity 2018, 49, 164-177.e6. [CrossRef]

53. Recovery Collaborative Group; Horby, P.; Lim, W.S.; Emberson, J.R.; Mafham, M.; Bell, J.L.; Linsell, L.; Staplin, N.; Brightling, C.; Ustianowski, A.; et al. Dexamethasone in Hospitalized Patients with COVID-19. N. Engl. J. Med. 2021, 384, $693-704$.

54. Bonaventura, A.; Montecucco, F. Steroid-Induced Hyperglycemia: An Underdiagnosed Problem or Clinical Inertia? A Narrative Review. Diabetes Res. Clin. Pract. 2018, 139, 203-220. [CrossRef] [PubMed]

55. Saand, A.R.; Flores, M.; Kewan, T.; Alqaisi, S.; Alwakeel, M.; Griffiths, L.; Wang, X.; Han, X.; Burton, R.; Al-Jaghbeer, M.J.; et al. Does Inpatient Hyperglycemia Predict a Worse Outcome in COVID-19 Intensive Care Unit Patients? J. Diabetes 2021, 13, 253-260. [CrossRef] 
56. Hamming, I.; Timens, W.; Bulthuis, M.L.; Lely, A.T.; Navis, G.; van Goor, H. Tissue Distribution of Ace2 Protein, the Functional Receptor for Sars Coronavirus. A First Step in Understanding Sars Pathogenesis. J. Pathol. 2004, 203, 631-637. [CrossRef] [PubMed]

57. Wang, F.; Wang, H.; Fan, J.; Zhang, Y.; Wang, H.; Zhao, Q. Pancreatic Injury Patterns in Patients with Coronavirus Disease 19 Pneumonia. Gastroenterology 2020, 159, 367-370. [CrossRef] [PubMed]

58. Yang, L.; Han, Y.; Nilsson-Payant, B.E.; Gupta, V.; Wang, P.; Duan, X.; Tang, X.; Zhu, J.; Zhao, Z.; Jaffre, F.; et al. A Human Pluripotent Stem Cell-Based Platform to Study SARS-CoV-2 Tropism and Model Virus Infection in Human Cells and Organoids. Cell Stem Cell 2020, 27, 125-136.e7. [CrossRef] [PubMed]

59. Muller, J.A.; Gross, R.; Conzelmann, C.; Kruger, J.; Merle, U.; Steinhart, J.; Weil, T.; Koepke, L.; Bozzo, C.P.; Read, C.; et al. SARS-CoV-2 Infects and Replicates in Cells of the Human Endocrine and Exocrine Pancreas. Nat. Metab. 2021, 3, 149-165. [CrossRef] [PubMed]

60. Niu, M.J.; Yang, J.K.; Lin, S.S.; Ji, X.J.; Guo, L.M. Loss of Angiotensin-Converting Enzyme 2 Leads to Impaired Glucose Homeostasis in Mice. Endocrine 2008, 34, 56-61. [CrossRef] [PubMed]

61. Jonietz, E. Pathology: Cause and Effect. Nature 2012, 485, S10-S11. [CrossRef] [PubMed]

62. Coppieters, K.T.; Boettler, T.; von Herrath, M. Virus Infections in Type 1 Diabetes. Cold Spring Harb. Perspect. Med. 2021, 2, a007682. [CrossRef] [PubMed]

63. Negro, F.; Alaei, M. Hepatitis C Virus and Type 2 Diabetes. World J. Gastroenterol. 2009, 15, 1537-1547. [CrossRef] [PubMed]

64. Nagafuchi, S.; Kamada-Hibio, Y.; Hirakawa, K.; Tsutsu, N.; Minami, M.; Okada, A.; Kai, K.; Teshima, M.; Moroishi, A.; Murakami, Y.; et al. Tyk2 Promoter Variant and Diabetes Mellitus in the Japanese. EBioMedicine 2015, 2, 744-749. [CrossRef] [PubMed]

65. Izumi, K.; Mine, K.; Inoue, Y.; Teshima, M.; Ogawa, S.; Kai, Y.; Kurafuji, T.; Hirakawa, K.; Miyakawa, D.; Ikeda, H.; et al. Reduced Tyk2 Gene Expression in $\beta$-Cells Due to Natural Mutation Determines Susceptibility to Virus-Induced Diabetes. Nat. Commun. 2015, 6, 6748. [CrossRef]

66. Chee, Y.J.; Ng, S.J.H.; Yeoh, E. Diabetic Ketoacidosis Precipitated by COVID-19 in a Patient with Newly Diagnosed Diabetes Mellitus. Diabetes Res. Clin. Pract. 2020, 164, 108166. [CrossRef] [PubMed]

67. Hollstein, T.; Schulte, D.M.; Schulz, J.; Gluck, A.; Ziegler, A.G.; Bonifacio, E.; Wendorff, M.; Franke, A.; Schreiber, S.; Bornstein, S.R.; et al. Autoantibody-Negative Insulin-Dependent Diabetes Mellitus after SARS-CoV-2 Infection: A Case Report. Nat. Metab. 2020, 2, 1021-1024. [CrossRef] [PubMed]

68. Armeni, E.; Aziz, U.; Qamar, S.; Nasir, S.; Nethaji, C.; Negus, R.; Murch, N.; Beynon, H.C.; Bouloux, P.; Rosenthal, M.; et al. Protracted Ketonaemia in Hyperglycaemic Emergencies in COVID-19: A Retrospective Case Series. Lancet Diabetes Endocrinol. 2020, 8, 660-663. [CrossRef]

69. Zhou, W.; Ye, S.; Wang, W.; Li, S.; Hu, Q. Clinical Features of COVID-19 Patients with Diabetes and Secondary Hyperglycemia. J. Diabetes Res. 2020, 2020, 3918723. [CrossRef]

70. Barrett, C.E.; Koyama, A.K.; Alvarez, P.; Chow, W.; Lundeen, E.A.; Perrine, C.G.; Pavkov, M.E.; Rolka, D.B.; Wiltz, J.L.; BullOtterson, L.; et al. Risk for Newly Diagnosed Diabetes $>30$ Days after SARS-CoV-2 Infection among Persons Aged $<18$ Years-United States, 1 March 2020-28 June 2021. MMWR Morb. Mortal. Wkly. Rep. 2022, 71, 59-65. [PubMed]

71. Ebekozien, O.A.; Noor, N.; Gallagher, M.P.; Alonso, G.T. Type 1 Diabetes and COVID-19: Preliminary Findings from a Multicenter Surveillance Study in the U.S. Diabetes Care 2020, 43, e83-e85. [CrossRef] [PubMed]

72. Unsworth, R.; Wallace, S.; Oliver, N.S.; Yeung, S.; Kshirsagar, A.; Naidu, H.; Kwong, R.M.W.; Kumar, P.; Logan, K.M. New-Onset Type 1 Diabetes in Children During COVID-19: Multicenter Regional Findings in the U.K. Diabetes Care 2020, 43, e170-e171. [CrossRef] [PubMed]

73. Vlad, A.; Serban, V.; Timar, R.; Sima, A.; Botea, V.; Albai, O.; Timar, B.; Vlad, M. Increased Incidence of Type 1 Diabetes During the COVID-19 Pandemic in Romanian Children. Medicina (Kaunas) 2021, 57, 973. [CrossRef] [PubMed]

74. Kamrath, C.; Monkemoller, K.; Biester, T.; Rohrer, T.R.; Warncke, K.; Hammersen, J.; Holl, R.W. Ketoacidosis in Children and Adolescents with Newly Diagnosed Type 1 Diabetes During the COVID-19 Pandemic in Germany. JAMA 2020, 324, 801-804. [CrossRef]

75. Lawrence, C.; Seckold, R.; Smart, C.; King, B.R.; Howley, P.; Feltrin, R.; Smith, T.A.; Roy, R.; Lopez, P. Increased Paediatric Presentations of Severe Diabetic Ketoacidosis in an Australian Tertiary Centre During the COVID-19 Pandemic. Diabet. Med. 2021, 38, e14417. [CrossRef] [PubMed]

76. Zubkiewicz-Kucharska, A.; Seifert, M.; Stepkowski, M.; Noczynska, A. Diagnosis of Type 1 Diabetes During the SARS-CoV-2 Pandemic: Does Lockdown Affect the Incidence and Clinical Status of Patients? Adv. Clin. Exp. Med. 2021, 30, 127-134. [CrossRef]

77. Tittel, S.R.; Rosenbauer, J.; Kamrath, C.; Ziegler, J.; Reschke, F.; Hammersen, J.; Monkemoller, K.; Pappa, A.; Kapellen, T.; Holl, R.W.; et al. Did the COVID-19 Lockdown Affect the Incidence of Pediatric Type 1 Diabetes in Germany? Diabetes Care 2020, 43, e172-e173. [CrossRef] [PubMed]

78. Rabbone, I.; Schiaffini, R.; Cherubini, V.; Maffeis, C.; Scaramuzza, A. Endocrinology Diabetes Study Group of the Italian Society for Pediatric, and Diabetes. Has COVID-19 Delayed the Diagnosis and Worsened the Presentation of Type 1 Diabetes in Children? Diabetes Care 2020, 43, 2870-2872. [CrossRef]

79. Hippich, M.; Holthaus, L.; Assfalg, R.; Zapardiel-Gonzalo, J.; Kapfelsperger, H.; Heigermoser, M.; Haupt, F.; Ewald, D.A.; Welzhofer, T.C.; Marcus, B.A.; et al. A Public Health Antibody Screening Indicates a 6-Fold Higher SARS-CoV-2 Exposure Rate Than Reported Cases in Children. Med. (N. Y.) 2021, 2, 149-163.e4. [CrossRef] 
80. Kusmartseva, I.; Wu, W.; Syed, F.; van der Heide, V.; Jorgensen, M.; Joseph, P.; Tang, X.; Candelario-Jalil, E.; Yang, C.; Nick, H.; et al. Expression of SARS-CoV-2 Entry Factors in the Pancreas of Normal Organ Donors and Individuals with COVID-19. Cell Metab. 2020, 32, 1041-1051.e6. [CrossRef] [PubMed]

81. Ibrahim, S.; Monaco, G.S.F.; Sims, E.K. Not So Sweet and Simple: Impacts of SARS-CoV-2 on the $\beta$ Cell. Islets 2021, 4, 66-79. [CrossRef]

82. Bornstein, S.R.; Rubino, F.; Khunti, K.; Mingrone, G.; Hopkins, D.; Birkenfeld, A.L.; Boehm, B.; Amiel, S.; Holt, R.I.; Skyler, J.S.; et al. Practical Recommendations for the Management of Diabetes in Patients with COVID-19. Lancet Diabetes Endocrinol. 2020, 8 , 546-550. [CrossRef]

83. Montefusco, L.; Nasr, M.B.; D’Addio, F.; Loretelli, C.; Rossi, A.; Pastore, I.; Daniele, G.; Abdelsalam, A.; Maestroni, A.; Dell'Acqua, M.; et al. Acute and Long-Term Disruption of Glycometabolic Control after SARS-CoV-2 Infection. Nat. Metab. 2021, 3, 774-785. [CrossRef] [PubMed]

84. Chen, M.; Zhu, B.; Chen, D.; Hu, X.; Xu, X.; Shen, W.J.; Hu, C.; Li, J.; Qu, S. COVID-19 May Increase the Risk of Insulin Resistance in Adult Patients without Diabetes: A 6-Month Prospective Study. Endocr. Pract. 2021, 27, 834-841. [CrossRef] [PubMed]

85. Kumar, A.; Faiq, M.A.; Pareek, V.; Raza, K.; Narayan, R.K.; Prasoon, P.; Kumar, P.; Kulandhasamy, M.; Kumari, C.; Kant, K.; et al. Relevance of SARS-CoV-2 Related Factors ACE2 and TMPRSS2 Expressions in Gastrointestinal Tissue with Pathogenesis of Digestive Symptoms, Diabetes-Associated Mortality, and Disease Recurrence in COVID-19 Patients. Med. Hypotheses 2020, 144, 110271. [CrossRef] [PubMed]

86. Maslo, C.; Friedland, R.; Toubkin, M.; Laubscher, A.; Akaloo, T.; Kama, B. Characteristics and Outcomes of Hospitalized Patients in South Africa During the COVID-19 Omicron Wave Compared with Previous Waves. JAMA 2021, 327, 583-584. [CrossRef]

87. Halfmann, P.J.; Iida, S.; Iwatsuki-Horimoto, K.; Maemura, T.; Kiso, M.; Scheaffer, S.M.; Darling, T.L.; Joshi, A.; Loeber, S.; Singh, G.; et al. SARS-CoV-2 Omicron Virus Causes Attenuated Disease in Mice and Hamsters. Nature, 2022, Epub ahead of print. [CrossRef]

88. Meng, B.; Abdullahi, A.; Ferreira, I.; Goonawardane, N.; Saito, A.; Kimura, I.; Yamasoba, D.; Gerber, P.P.; Fatihi, S.; Rathore, S.; et al. Altered TMPRSS2 Usage by SARS-CoV-2 Omicron Impacts Tropism and Fusogenicity. Nature, 2022, Epub ahead of print. [CrossRef]

89. Liu, L.; Iketani, S.; Guo, Y.; Chan, J.F.; Wang, M.; Liu, L.; Luo, Y.; Chu, H.; Huang, Y.; Nair, M.S.; et al. Striking Antibody Evasion Manifested by the Omicron Variant of SARS-CoV-2. Nature 2021, 602, 676-681. [CrossRef] [PubMed]

90. Dong, M.; Zhang, J.; Ma, X.; Tan, J.; Chen, L.; Liu, S.; Xin, Y.; Zhuang, L. Ace2, Tmprss2 Distribution and Extrapulmonary Organ Injury in Patients with COVID-19. Biomed. Pharm. 2020, 131, 110678. [CrossRef]

91. European Centre for Disease Prevention and Control. Available online: https://www.ecdc.europa.eu/en/covid-19 (accessed on 14 February 2022).

92. Dao, T.L.; Hoang, V.T.; Colson, P.; Lagier, J.C.; Million, M.; Raoult, D.; Levasseur, A.; Gautret, P. SARS-CoV-2 Infectivity and Severity of COVID-19 According to SARS-CoV-2 Variants: Current Evidence. J. Clin. Med. 2021, 10, 2635. [CrossRef] [PubMed]

93. England Public Health. SARS-CoV-2 Variants of Concern and Variants under Investigation in England: Technical Briefing 10; England Public Health: London, UK, 2021.

94. Viana, R.; Moyo, S.; Amoako, D.G.; Tegally, H.; Scheepers, C.; Althaus, C.L.; Anyaneji, U.J.; Bester, P.A.; Boni, M.F.; Chand, M.; et al. Rapid Epidemic Expansion of the SARS-CoV-2 Omicron Variant in Southern Africa. Nature, 2022, Epub ahead of print.

95. Nishiura, H.; Ito, K.; Anzai, A.; Kobayashi, T.; Piantham, C.; Rodriguez-Morales, A.J. Relative Reproduction Number of SARS-CoV-2 Omicron (B.1.1.529) Compared with Delta Variant in South Africa. J. Clin. Med. 2021, 11, 30. [CrossRef]

96. Ito, K.; Piantham, C.; Nishiura, H. Relative Instantaneous Reproduction Number of Omicron Sars-Cov-2 Variant with Respect to the Delta Variant in Denmark. J. Med. Virol. 2021. [CrossRef]

97. Lyngse, F.P.; Mortensen, L.H.; Denwood, M.J.; Christiansen, L.E.; Møller, C.H.; Skov, R.L.; Spiess, K.; Fomsgaard, A.; Lassaunière, M.M.; Rasmussen, M.; et al. SARS-Cov-2 Omicron VOC Transmission in Danish Households. medRxiv 2021. [CrossRef]

98. Sheikh, A.; McMenamin, J.; Taylor, B.; Robertson, C. SARS-CoV-2 Delta VOC in Scotland: Demographics, Risk of Hospital Admission, and Vaccine Effectiveness. Lancet 2021, 397, 2461-2462. [CrossRef]

99. Twohig, K.A.; Nyberg, T.; Zaidi, A.; Thelwall, S.; Sinnathamby, M.A.; Aliabadi, S.; Seaman, S.R.; Harris, R.J.; Hope, R.; LopezBernal, J.; et al. Hospital Admission and Emergency Care Attendance Risk for SARS-CoV-2 Delta (B.1.617.2) Compared with Alpha (B.1.1.7) Variants of Concern: A Cohort Study. Lancet Infect. Dis. 2022, 22, 35-42. [CrossRef]

100. Pulliam, J.R.; van Schalkwyk, C.; Govender, N.; von Gottberg, A.; Cohen, C.; Groome, M.J.; Dushoff, J.; Mlisana, K.; Moultrie, H. Increased Risk of SARS-CoV-2 Reinfection Associat Ed with Emergence of the Omicron Variant in South Africa. medRxiv 2021. [CrossRef]

101. Alexandraki, K.I.; Piperi, C.; Ziakas, P.D.; Apostolopoulos, N.V.; Makrilakis, K.; Syriou, V.; Diamanti-Kandarakis, E.; Kaltsas, G.; Kalofoutis, A. Cytokine Secretion in Long-Standing Diabetes Mellitus Type 1 and 2: Associations with Low-Grade Systemic Inflammation. J. Clin. Immunol. 2008, 28, 314-321. [CrossRef] [PubMed]

102. Kim, J.H.; Park, K.; Lee, S.B.; Kang, S.; Park, J.S.; Ahn, C.W.; Nam, J.S. Relationship between Natural Killer Cell Activity and Glucose Control in Patients with Type 2 Diabetes and Prediabetes. J. Diabetes Investig. 2019, 10, 1223-1228. [CrossRef] [PubMed]

103. Jagannathan-Bogdan, M.; McDonnell, M.E.; Shin, H.; Rehman, Q.; Hasturk, H.; Apovian, C.M.; Nikolajczyk, B.S. Elevated Proinflammatory Cytokine Production by a Skewed T Cell Compartment Requires Monocytes and Promotes Inflammation in Type 2 Diabetes. J. Immunol. 2011, 186, 1162-1172. [CrossRef] [PubMed] 
104. Hodgson, K.; Morris, J.; Bridson, T.; Govan, B.; Rush, C.; Ketheesan, N. Immunological Mechanisms Contributing to the Double Burden of Diabetes and Intracellular Bacterial Infections. Immunology 2015, 144, 171-185. [CrossRef]

105. Tang, Q.; Adams, J.Y.; Penaranda, C.; Melli, K.; Piaggio, E.; Sgouroudis, E.; Piccirillo, C.A.; Salomon, B.L.; Bluestone, J.A. Central Role of Defective Interleukin-2 Production in the Triggering of Islet Autoimmune Destruction. Immunity 2008, 28, 687-697. [CrossRef] [PubMed]

106. Tay, M.Z.; Poh, C.M.; Renia, L.; MacAry, P.A.; Ng, L.F.P. The Trinity of COVID-19: Immunity, Inflammation and Intervention. Nat. Rev. Immunol. 2020, 20, 363-374. [CrossRef]

107. Zhou, P.; Yang, X.L.; Wang, X.G.; Hu, B.; Zhang, L.; Zhang, W.; Si, H.R.; Zhu, Y.; Li, B.; Huang, C.L.; et al. A Pneumonia Outbreak Associated with a New Coronavirus of Probable Bat Origin. Nature 2020, 579, 270-273. [CrossRef] [PubMed]

108. Hoffmann, M.; Kleine-Weber, H.; Schroeder, S.; Kruger, N.; Herrler, T.; Erichsen, S.; Schiergens, T.S.; Herrler, G.; Wu, N.H.; Nitsche, A.; et al. SARS-CoV-2 Cell Entry Depends on ACE2 and TMPRSS2 and Is Blocked by a Clinically Proven Protease Inhibitor. Cell 2020, 181, 271-280.e8. [CrossRef]

109. Li, W.; Moore, M.J.; Vasilieva, N.; Sui, J.; Wong, S.K.; Berne, M.A.; Somasundaran, M.; Sullivan, J.L.; Luzuriaga, K.; Greenough, T.C.; et al. Angiotensin-Converting Enzyme 2 Is a Functional Receptor for the Sars Coronavirus. Nature 2003, 426, 450-454. [CrossRef] [PubMed]

110. Eguchi, S.; Kawai, T.; Scalia, R.; Rizzo, V. Understanding Angiotensin Ii Type 1 Receptor Signaling in Vascular Pathophysiology. Hypertension 2018, 71, 804-810. [CrossRef] [PubMed]

111. Kuba, K.; Imai, Y.; Rao, S.; Gao, H.; Guo, F.; Guan, B.; Huan, Y.; Yang, P.; Zhang, Y.; Deng, W.; et al. A Crucial Role of Angiotensin Converting Enzyme 2 (Ace2) in Sars Coronavirus-Induced Lung Injury. Nat. Med. 2005, 11, 875-879. [CrossRef] [PubMed]

112. Roca-Ho, H.; Riera, M.; Palau, V.; Pascual, J.; Soler, M.J. Characterization of ACE and ACE2 Expression within Different Organs of the Nod Mouse. Int. J. Mol. Sci. 2017, 18, 563. [CrossRef] [PubMed]

113. Taneera, J.; El-Huneidi, W.; Hamad, M.; Mohammed, A.K.; Elaraby, E.; Hachim, M.Y. Expression Profile of SARS-CoV-2 Host Receptors in Human Pancreatic Islets Revealed Upregulation of ACE2 in Diabetic Donors. Biology 2020, 9, 215. [CrossRef] [PubMed]

114. Avogaro, A.; Albiero, M.; Menegazzo, L.; de Kreutzenberg, S.; Fadini, G.P. Endothelial Dysfunction in Diabetes: The Role of Reparatory Mechanisms. Diabetes Care 2011, 34 (Suppl. 2), S285-S290. [CrossRef] [PubMed]

115. Domingueti, C.P.; Dusse, L.M.; Carvalho, M.; de Sousa, L.P.; Gomes, K.B.; Fernandes, A.P. Diabetes Mellitus: The Linkage between Oxidative Stress, Inflammation, Hypercoagulability and Vascular Complications. J. Diabetes Complicat. 2016, 30, 738-745. [CrossRef] [PubMed]

116. Carr, M.E. Diabetes Mellitus: A Hypercoagulable State. J. Diabetes Complicat. 2001, 15, 44-54. [CrossRef]

117. Anandhalakshmi, S.; Manikandan, S.; Ganeshkumar, P.; Ramachandran, C. Alveolar Gas Exchange and Pulmonary Functions in Patients with Type Ii Diabetes Mellitus. J. Clin. Diagn. Res. 2013, 7, 1874-1877.

118. Stegenga, M.E.; van der Crabben, S.N.; Blümer, R.M.; Levi, M.; Meijers, J.C.; Serlie, M.J.; Tanck, M.W.; Sauerwein, H.P.; van der Poll, T. Hyperglycemia Enhances Coagulation and Reduces Neutrophil Degranulation, Whereas Hyperinsulinemia Inhibits Fibrinolysis During Human Endotoxemia. Blood 2008, 112, 82-89. [CrossRef] [PubMed]

119. Varga, Z.; Flammer, A.J.; Steiger, P.; Haberecker, M.; Andermatt, R.; Zinkernagel, A.S.; Mehra, M.R.; Schuepbach, R.A.; Ruschitzka, F.; Moch, H. Endothelial Cell Infection and Endotheliitis in COVID-19. Lancet 2020, 395, 1417-1418. [CrossRef]

120. Codo, A.C.; Davanzo, G.G.; Monteiro, L.B.; de Souza, G.F.; Muraro, S.P.; Virgilio-da-Silva, J.V.; Prodonoff, J.S.; Carregari, V.C.; de Biagi, C.A., Jr.; Crunfli, F.; et al. Elevated Glucose Levels Favor SARS-CoV-2 Infection and Monocyte Response through a Hif-1 $\alpha$ /Glycolysis-Dependent Axis. Cell Metab. 2020, 32, 498-499. [CrossRef]

121. Wing, P.A.C.; Keeley, T.P.; Zhuang, X.; Lee, J.Y.; Prange-Barczynska, M.; Tsukuda, S.; Morgan, S.B.; Harding, A.C.; Argles, I.L.A.; Kurlekar, S.; et al. Hypoxic and Pharmacological Activation of Hif Inhibits SARS-CoV-2 Infection of Lung Epithelial Cells. Cell Rep. 2021, 35, 109020. [CrossRef] [PubMed]

122. Gandhi, R.T.; Lynch, J.B.; del Rio, C. Mild or Moderate COVID-19. N. Engl. J. Med. 2020, 383, 1757-1766. [CrossRef] [PubMed]

123. Rayman, G.; Lumb, A.N.; Kennon, B.; Cottrell, C.; Nagi, D.; Page, E.; Voigt, D.; Courtney, H.C.; Atkins, H.; Higgins, K.; et al. Dexamethasone Therapy in COVID-19 Patients: Implications and Guidance for the Management of Blood Glucose in People with and without Diabetes. Diabet. Med. 2021, 38, e14378. [CrossRef] [PubMed]

124. Zhang, W.; Xu, Y.Z.; Liu, B.; Wu, R.; Yang, Y.Y.; Xiao, X.Q.; Zhang, X. Pioglitazone Upregulates Angiotensin Converting Enzyme 2 Expression in Insulin-Sensitive Tissues in Rats with High-Fat Diet-Induced Nonalcoholic Steatohepatitis. Sci. World J. 2014, 2014, 603409. [CrossRef] [PubMed]

125. Romani-Perez, M.; Outeirino-Iglesias, V.; Moya, C.M.; Santisteban, P.; Gonzalez-Matias, L.C.; Vigo, E.; Mallo, F. Activation of the Glp-1 Receptor by Liraglutide Increases ACE2 Expression, Reversing Right Ventricle Hypertrophy, and Improving the Production of Sp-a and Sp-B in the Lungs of Type 1 Diabetes Rats. Endocrinology 2015, 156, 3559-3569. [CrossRef] [PubMed]

126. Salem, E.S.; Grobe, N.; Elased, K.M. Insulin Treatment Attenuates Renal ADAM17 and ACE2 Shedding in Diabetic Akita Mice. Am. J. Physiol. Renal. Physiol. 2014, 306, F629-F639. [CrossRef] [PubMed]

127. Kristofi, R.; Eriksson, J.W. Metformin as an Anti-Inflammatory Agent: A Short Review. J. Endocrinol. 2021, 251, R11-R22. [CrossRef]

128. Carvalho, M.V.; Goncalves-de-Albuquerque, C.F.; Silva, A.R. Ppar Gamma: From Definition to Molecular Targets and Therapy of Lung Diseases. Int. J. Mol. Sci. 2021, 22, 805. [CrossRef] 
129. D’Marco, L.; Morillo, V.; Gorriz, J.L.; Suarez, M.K.; Nava, M.; Ortega, A.; Parra, H.; Villasmil, N.; Rojas-Quintero, J.; Bermudez, V. Sglt2i and Glp-1ra in Cardiometabolic and Renal Diseases: From Glycemic Control to Adipose Tissue Inflammation and Senescence. J Diabetes Res. 2021, 2021, 9032378. [CrossRef] [PubMed]

130. Lee, Y.S.; Jun, H.S. Anti-Inflammatory Effects of Glp-1-Based Therapies Beyond Glucose Control. Mediat. Inflamm. 2016, 2016, 3094642. [CrossRef] [PubMed]

131. Shao, S.; Xu, Q.; Yu, X.; Pan, R.; Chen, Y. Dipeptidyl Peptidase 4 Inhibitors and Their Potential Immune Modulatory Functions. Pharmacol. Ther. 2020, 209, 107503. [CrossRef]

132. Lampasona, V.; Secchi, M.; Scavini, M.; Bazzigaluppi, E.; Brigatti, C.; Marzinotto, I.; Davalli, A.; Caretto, A.; Laurenzi, A.; Martinenghi, S.; et al. Antibody Response to Multiple Antigens of SARS-CoV-2 in Patients with Diabetes: An Observational Cohort Study. Diabetologia 2020, 63, 2548-2558. [CrossRef]

133. Dispinseri, S.; Lampasona, V.; Secchi, M.; Cara, A.; Bazzigaluppi, E.; Negri, D.; Brigatti, C.; Pirillo, M.F.; Marzinotto, I.; Borghi, M.; et al. Robust Neutralizing Antibodies to SARS-CoV-2 Develop and Persist in Subjects with Diabetes and COVID-19 Pneumonia. J. Clin. Endocrinol. Metab. 2021, 106, 1472-1481. [CrossRef]

134. Perez-Belmonte, L.M.; Torres-Pena, J.D.; Lopez-Carmona, M.D.; Ayala-Gutierrez, M.M.; Fuentes-Jimenez, F.; Huerta, L.J.; Munoz, J.A.; Rubio-Rivas, M.; Madrazo, M.; Garcia, M.G.; et al. Mortality and Other Adverse Outcomes in Patients with Type 2 Diabetes Mellitus Admitted for COVID-19 in Association with Glucose-Lowering Drugs: A Nationwide Cohort Study. BMC Med. 2020, 18, 359. [CrossRef]

135. Wang, J.; Cooper, J.M.; Gokhale, K.; Acosta-Mena, D.; Dhalla, S.; Byne, N.; Chandan, J.S.; Anand, A.; Okoth, K.; Subramanian, A.; et al. Association of Metformin with Susceptibility to COVID-19 in People with Type 2 Diabetes. J. Clin. Endocrinol. Metab. 2021, 106, 1255-1268. [CrossRef] [PubMed]

136. Oh, T.K.; Song, I.A. Metformin Use and Risk of COVID-19 among Patients with Type Ii Diabetes Mellitus: An Nhis-COVID-19 Database Cohort Study. Acta Diabetol. 2021, 58, 771-778. [CrossRef]

137. Wargny, M.; Potier, L.; Gourdy, P.; Pichelin, M.; Amadou, C.; Benhamou, P.Y.; Bonnet, J.B.; Bordier, L.; Bourron, O.; Chaumeil, C.; et al. Predictors of Hospital Discharge and Mortality in Patients with Diabetes and COVID-19: Updated Results from the Nationwide Coronado Study. Diabetologia 2021, 64, 778-794. [CrossRef] [PubMed]

138. Luo, P.; Qiu, L.; Liu, Y.; Liu, X.; Zheng, J.; Xue, H.; Liu, W.; Liu, D.; Li, J. Metformin Treatment Was Associated with Decreased Mortality in COVID-19 Patients with Diabetes in a Retrospective Analysis. Am. J. Trop. Med. Hyg. 2020, 103, 69-72. [CrossRef] [PubMed]

139. Crouse, A.B.; Grimes, T.; Li, P.; Might, M.; Ovalle, F.; Shalev, A. Metformin Use Is Associated with Reduced Mortality in a Diverse Population with COVID-19 and Diabetes. Front. Endocrinol. 2020, 11, 600439. [CrossRef] [PubMed]

140. Bramante, C.T.; Ingraham, N.E.; Murray, T.A.; Marmor, S.; Hovertsen, S.; Gronski, J.; McNeil, C.; Feng, R.; Guzman, G.; Abdelwahab, N.; et al. Metformin and Risk of Mortality in Patients Hospitalised with COVID-19: A Retrospective Cohort Analysis. Lancet Healthy Longev. 2021, 2, e34-e41. [CrossRef]

141. Sainsbury, C.; Wang, J.; Gokhale, K.; Acosta-Mena, D.; Dhalla, S.; Byne, N.; Chandan, J.S.; Anand, A.; Cooper, J.; Okoth, K.; et al. Sodium-Glucose Co-Transporter-2 Inhibitors and Susceptibility to COVID-19: A Populati.ion-Based Retrospective Cohort Study. Diabetes Obes. Metab. 2020, 23, 263-269. [CrossRef] [PubMed]

142. Noh, Y.; Oh, I.S.; Jeong, H.E.; Filion, K.B.; Yu, O.H.; Shin, J.Y. Association between Dpp-4 Inhibitors and COVID-19-Related Outcomes among Patients with Type 2 Diabetes. Diabetes Care 2021, 44, e64-e66. [CrossRef]

143. Fadini, G.P.; Morieri, M.L.; Longato, E.; Bonora, B.M.; Pinelli, S.; Selmin, E.; Voltan, G.; Falaguasta, D.; Tresso, S.; Costantini, G.; et al. Exposure to Dipeptidyl-Peptidase-4 Inhibitors and COVID-19 among People with Type 2 Diabetes: A Case-Control Study. Diabetes Obes. Metab. 2020, 22, 1946-1950. [CrossRef] [PubMed]

144. Roussel, R.; Darmon, P.; Pichelin, M.; Goronflot, T.; Abouleka, Y.; Bachir, L.A.; Allix, I.; Ancelle, D.; Barraud, S.; Bordier, L.; et al. Use of Dipeptidyl Peptidase-4 Inhibitors and Prognosis of COVID-19 in Hospitalized Patients with Type 2 Diabetes: A Propensity Score Analysis from the Coronado Study. Diabetes Obes. Metab. 2021, 23, 1162-1172. [CrossRef] [PubMed]

145. Mirani, M.; Favacchio, G.; Carrone, F.; Betella, N.; Biamonte, E.; Morenghi, E.; Mazziotti, G.; Lania, A.G. Impact of Comorbidities and Glycemia at Admission and Dipeptidyl Peptidase 4 Inhibitors in Patients with Type 2 Diabetes with COVID-19: A Case Series from an Academic Hospital in Lombardy, Italy. Diabetes Care 2020, 43, 3042-3049. [CrossRef]

146. Solerte, S.B.; D'Addio, F.; Trevisan, R.; Lovati, E.; Rossi, A.; Pastore, I.; Dell'Acqua, M.; Ippolito, E.; Scaranna, C.; Bellante, R.; et al. Sitagliptin Treatment at the Time of Hospitalization Was Associated with Reduced Mortality in Patients with Type 2 Diabetes and COVID-19: A Multicenter, Case-Control, Retrospective, Observational Study. Diabetes Care 2020, 43, 2999-3006. [CrossRef] [PubMed]

147. Dalan, R.; Dalan, R.; Ang, L.W.; Tan, W.Y.; Fong, S.W.; Tay, W.C.; Chan, Y.H.; Renia, L.; Ng, L.F.; Lye, D.C.; et al. The Association of Hypertension and Diabetes Pharmacotherapy with COVID-19 Severity and Immune Signatures: An Observational Study. Eur. Heart J. Cardiovasc. Pharmacother. 2021, 7, e48-e51. [CrossRef] [PubMed]

148. Hansen, T.K.; Thiel, S.; Wouters, P.J.; Christiansen, J.S.; van den Berghe, G. Intensive Insulin Therapy Exerts Antiinflammatory Effects in Critically Ill Patients and Counteracts the Adverse Effect of Low Mannose-Binding Lectin Levels. J. Clin. Endocrinol. Metab. 2003, 88, 1082-1088. [CrossRef] [PubMed] 
149. Chen, Y.; Yang, D.; Cheng, B.; Chen, J.; Peng, A.; Yang, C.; Liu, C.; Xiong, M.; Deng, A.; Zhang, Y.; et al. Clinical Characteristics and Outcomes of Patients with Diabetes and COVID-19 in Association with Glucose-Lowering Medication. Diabetes Care 2020, 43, 1399-1407. [CrossRef] [PubMed]

150. Yu, B.; Li, C.; Sun, Y.; Wang, D.W. Insulin Treatment Is Associated with Increased Mortality in Patients with COVID-19 and Type 2 Diabetes. Cell Metab. 2021, 33, 65-77.e2. [CrossRef] [PubMed] 